\title{
CAM VE RENK
}

\author{
Arş. Gör. Fatma ÇifTçi* \\ Prof. Mustafa AĞATEKiN**
}

\section{ÖZET}

Bu araştırma camın plastik ifade olanaklarına iliskin rengin cam sanatındaki kullanımlarının izini sürerken, camda renk ve anlatım ilişkisini inceleyerek bunu kullanan sanatçılara yer vermektedir. Rengin biçime yüklediği anlamlar dünyada cam malzemesini kullanan sanatçılar kapsamında ele alınmıştır.

İlk bölümde teknik açıdan camda renk olanaklarına değinilmiş, sanatçıların camı nasıl kullandiklarından örnekler verilerek teknik detaylara değinilmiştir. Renkle ilgili camın transparan yapısı göz önüne alınarak yapılan araştırmalara değinilmiş, ışı ve renk birlikteliğinin izi sürülmüştür. Anlatımda bu özellikleri kullanan sanatçlların eserleri üzerinden örnekler verilmiştir. Çizgisel ifade olanakları çerçevesinde neon uygulamaları ve roll-up tekniği kullanan sanatçıların biçim araştırmaları eser örnekleri eşliğinde sunulmuştur. Kompozisyonlarında rengi anlamin taşıyıcısı olarak kullanan sanatçılara yer verilmiş, rengi monokrom kullanan sanatçılara da değinilmiştir.

Anahtar Kelimeler: Cam, Renk, Çağdaş Sanat, Cam Sanatı.

${ }^{*}$ Dokuz Eylül Üniversitesi Güzel Sanatlar Fakültesi Seramikve Cam Tasarımı Bölümü Narlıdere- İzmir / fatma.ciftci@deu.edu.tr

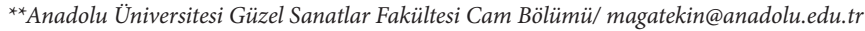




\title{
GLASS AND COLOUR
}

\author{
Res. Asst. Fatma ÇiFTçi* \\ Prof. Mustafa AĞATEKin**
}

\section{ABSTRACT}

This research traces the possibilities of plastic expression regarding the color of the glass and ranks the artists who use it by examining the relationship between color and expression in glass. The meaning that color adds to shape has been investigated in the scope of artists using glass in their works worldwide.

First of all, the technical aspects of glass regarding the possibilities of color are stated by giving examples of how artists use glass. The studies investigating color by taking into consideration of the transparent nature of glass are stated and the combination of light and color has been explored. In addition, the works of artists using glass and color are exemplified. Within the scope of linear expression possibilities, artists using neon applications and roll-up technique are presented through their art works. Finally, artists using color as a bearer of the meaning on their compositions, and artists using color monochrome are also briefly mentioned.

Keywords: Glass, Color, Contemporary Art, Glass Art.

\footnotetext{
${ }^{*}$ Dokuz Eylül University Faculty of Fine Arts Department of Ceramic and Glass Design Narlidere-İzmir / fatma.ciftci@deu.edu.tr

${ }^{* * A n a d o l u}$ University Faculty of Fine Arts Glass Department / magatekin@anadolu.edu.tr
}

This article is produced from the project numbered 1702 E046 accepted by BAP Commission of Anadolu University. 


\section{Gíriș}

"Renk, ister doğal olsun, ister suni olsun, ışıkla başlar ve ışıktan türer. Işs̆ğın az olduğu yerde renk de azdır; ışığın güçlü olduğu yerde, renk de yoğun olacaktır." (Ocvirk vd., 2015: 184). Rengin tarihsel bellekteki izleri incelendiğinde rengin kitleler üzerinde uyandırdığı anlamların, bugünün küresel dünyasında uzlaşılmış bilimsel dayanaklara oturtulduğu görülmektedir. Üçboyutlu biçimin kazandığı uzam da genellikle 1şıkla birlikte düşünülmektedir. Biçimin uzamı, kendi içine davet ettiği ışık ile değişir; şeffaf olmayan malzemeler kullanıldığında biçimde boşluklar oluşturulur, böylece bu alanlar biçime nefes aldırır. Rengin biçime yüklediği anlamlar konusunda değerli düşüncelerini belirten Ludwig Wittgenstein’a göre gri renk ışıldamayandır ve gri görünen her şey ışıktan yoksun olandır (Wittgenstein, 2007: 7e). Siyah renkte bir aynadan örnek verir, yansitma özelliğine sahip bir siyah yüzeyin biçime 'kirli' değil 'derin' bir anlam yüklediğinden bahseder (Wittgenstein, 2007: 8e). Camın transparan bir malzeme olması bu açıdan oldukça avantajıdır. Ancak malzemeyle çalışmak bazı dezavantajları ve zorlukları da beraberinde getirir.

Camda rengin ele alınışı zaman içerisinde bilimsel ve teknolojik buluşlar nispetinde değişiklik gösterir. Sanatçıların ulaşabildiği malzemeler zamanla sanatçının üzerinde deneyler yaptığ veya kimi zaman eserlerin oluşmasında belirleyici roller oynayan, onunla birlikte anılan biçimsel bir ögeye dönüşür. Malzemenin sınırlarını denemeye koyulan sanatçının bu girişimi bazen yeni bir teknik keşfetmesiyle sonuçlanır. Bu nedenle malzeme çeşitliliği ve tekniği cam biçimlendirmede önemli bir rol oynar.

\section{TEKNİK AÇIDAN CAMDA RENK OLANAKLARI}

Camda renk kullanımı, renkli üretilmiş camlarla olabildiği gibi sentetik boyalarla dekor biçiminde de uygulanabilmektedir. Renk kullanımının ilk örnekleri deneysel olup, cam üzerinde kalıcı olma kaygısı güdülerek yapılmamıştır. Cam teknolojisi hakkında yeterli bilgiye ulaşıldığında ise camın üretimi sırasında renklendirilmiş özel camlar kullanılmaya başlanır. Bu camlar şeffaf veya opak camlar olarak iki çeşittir. Şeffaf camlar geçirgenlikleri nedeniyle 1şı̆̆g daha iyi taşırken, opak camlar ışı̆̆ geçirmezler ve kimi zaman doku olarak plastik bir görüntü verirler; bu nedenle camda rengin ele alınışı ışıkla birlikte değerlendirilir. Renkli camları çeşitli büyüklüklerde cam granüller halinde, çubuk biçiminde ve pudra inceliğinde cam malzeme olarak bulmak mümkündür. Bu tip camlar çok renkli çalışılmasına olanak tanır. Özellikle Art Nouveau döneminde pate de verre tekniği ile üretilen çok renkli cam eserler bu nitelikte camlar kullanılarak biçimlendirilmiştir (Cummings, 2011: 21-49). Camın dokuyu aktarma özelliğinin gerçeğe yakın renklerle birleşimi hiperrealist heykeller yaratmayı mümkün hale getirir (Görsel 1). 


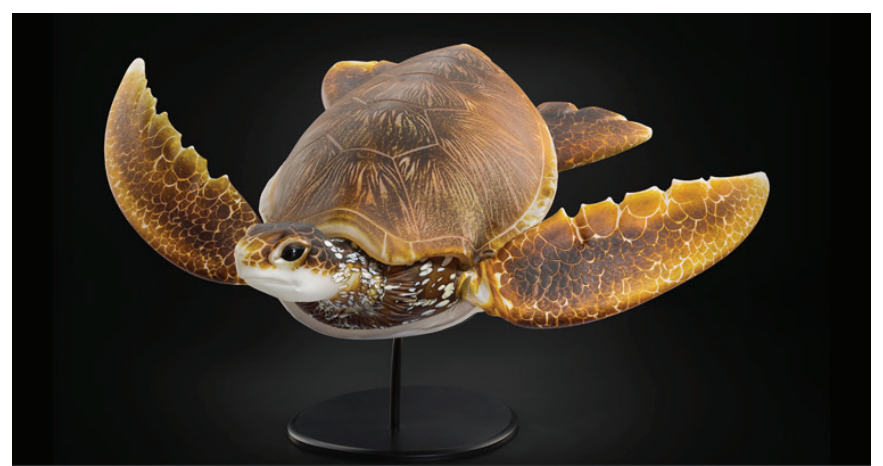

Görsel 1. Raven Skyriver, "Gyre - Green Sea Turtle”, 18" x 28" x 26", Cam, 2016, ABD.

Teknik açıdan camı renklendirme, resim sanatında olduğu gibi pigmentlerle oluşturulmaz, oksitlerle oluşturulur. Camların farklı renklerde karıştırılarak kullanılması birbiri içerisinde eriyip farklı renkler oluşmasına yol açmaz. Örneğin transparan mavi ile transparan sarı rengi birlikte eriterek kalıba döktügünüzde yeşil renkli bir cam elde etmezsiniz. Belki daha iyisini elde edersiniz; bu iki transparan renk bazı açlardan bakıldığında ışığın da yardımıyla izleyiciye yeşil rengi algılatabilir. Başka bir ifadeyle her iki cam da kendi içinde yapısal özelliğini kaybetmezken, renk etkisi bağlamında izleyicide yepyeni bir izlenim oluşturabilir. Cam kütle içerisine, baloncuk hapsedildiğinde ışı̆̆ı daha fazla içine alarak renkte birkaç farklı tonda renk etkisi yakalanması da mümkündür.

Cam ile renk ilişkisi irdelendiğinde anlaşılır ki renk tonları transparan camın kalınlığına ve hacmine göre değişiklik gösterir. En açık transparan renk kullanılsa bile, boyutta uzam arttıkça renkte koyulaşma görülür. Heike Brachlow’un 2012 yılında tamamladığı camda renk ile ilgili araştırmasında cam harmanını oksitlerle renklendirmiş ve renk denemelerini yaptığı formu seçerken bu özelliklere dikkat etmiştir. Brachlow, 2008 yılında renk tonu ve yoğunluk konusunda testlere başlamış ve camların kalınlığına, büyüklüğüne ve hacmine bağlı olarak rengin daha koyu algılanabileceği en uygun biçimi (Görsel 2)'deki gibi tariflemiştir. (Brachlow, 2012: 127)

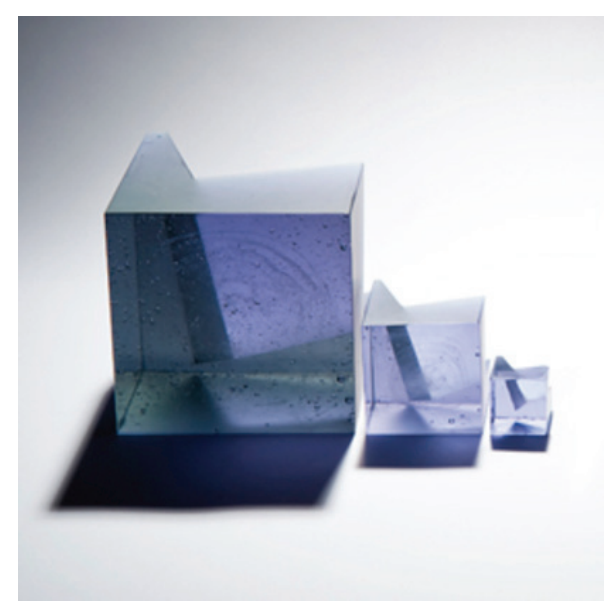

Görsel 2. Heike Brachlow, Cam, 2012, Birleşik Krallik. 

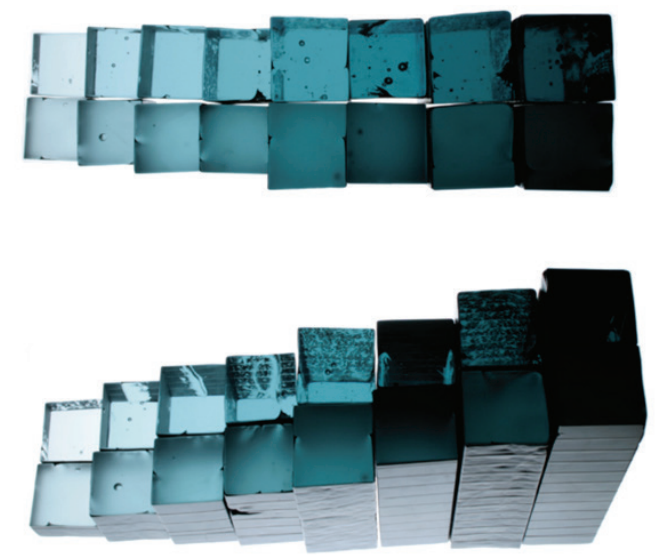

Görsel 3. Heike Brachlow, cam, Renk yoğunluğunu ölçme 4.5 × $4.5 \mathrm{~cm}$ Yükseklik: değişken ölçülerde

Bu prensipte camın daha fazla ışık alması sonucunda rengin gözle görünür biçimde azalması ve artması esastır. Bu bir nevi resim sanatındaki degrade geçişin karşılığıdır. Bazı sanatçıların camın bu özelliğinden faydalandıkları görülür. Örneğin (Görsel 4) Frantisek Vizner kütle cam biçimlerinde rengin hacimle birlikte azalmasını kullanan sanatçılardan biridir. Benzer şekilde -ancak anlamın taşıyıcısı olarak renk yerine ışık kullanan- Libenský ve Brychtovánın eserlerinde de ışığın kütle içerisinde dolaştığını izleriz.

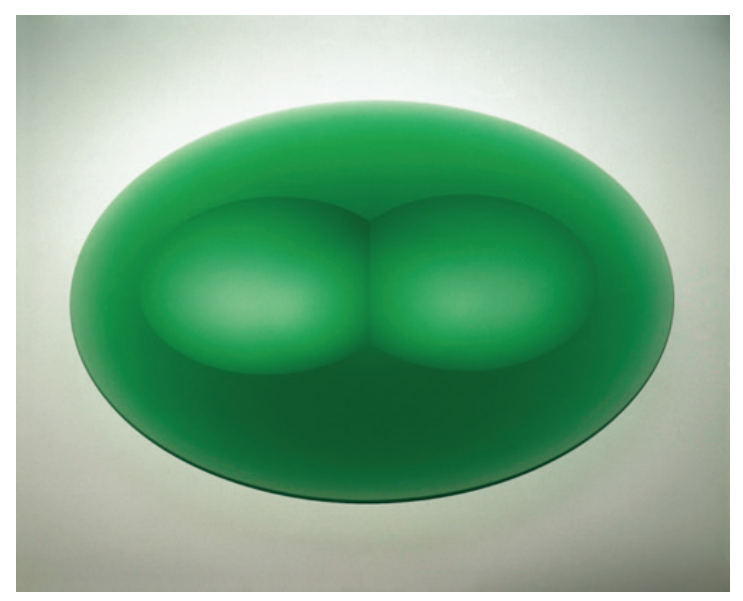

Görsel 4. Frantisek Vizner, “Tabak”, Çap: 45 cm, Cam, 1972, Çek Cumhuriyeti

Cam malzemesi kütlesel formlara izin verdiği gibi, çizgisel ifadeye de olanak tanır. Hem f1rında biçimlendirme tekniklerinde, hem üfleme tekniğinde, hem de neon sanatı* ve plazma tekniğiyle renkli çizgisel kompozisyonlar yaratmak mümkündür. Örneğin neon gazı -vb.- doldurulmuş cam tüpleriyle oluşturulmuş kompozisyonlarda, ışı̆̆ın camın içerisinden yansıması

\footnotetext{
*Yazarm 'Neon Sanati' tabirini kullanma nedeni: ABD California'da Museum of Neon Art(MoNA) ismiyle bir müze bulunmaktadır, bu müze plazma da dahil olmak üzere neon tekniklerin kullanıldı̆̆ı eserlerden bir koleksiyon oluşturmuştur. MoNA, bu alanda estetiği belirleyen kurum olmanın yanı sıra literatürü de etkilemiştir.
} 
kuvvetli çizgilerin oluşmasını sağlar. Bu etki sanatçıya mekândaki perspektifi değiştirmeye varana dek geniş olanaklar sağlar. Bu olanak optik sanatta cam ve ışı̆̆ı kullanan Dan Flavin gibi sanatçıların mekânda yanılsama yaratmasına ilham kaynağı olur (Görsel 5).

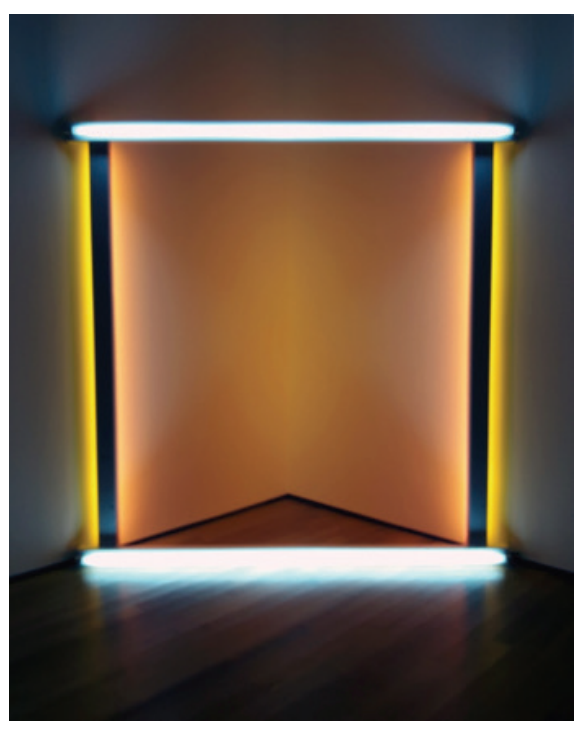

Görsel 5. Dan Flavin, "Untitled (to the 'innovator' of Wheeling Peachblow)", $200 \times 200 \times 8 \mathrm{~cm}$, Floresan ışılklar ve Metal tesisat. 1968, ABD

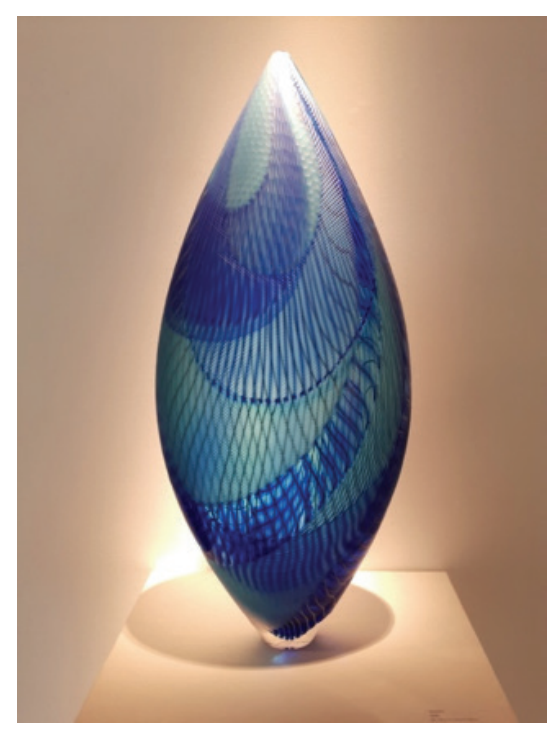

Görsel 6. Lino Tagliepietra, "Makah", $26 \times 11 \times 7$ ", Cam, 2008, ABD

Camda renk olanaklarından bir diğeri ise neon uygulamalarında gözlenir. Cam tüplerin içerisine doldurulan argon gazı ve cıva buharı mavi renk oluşturur, neon gazı kırmızı renk verir. Her iki gaz tüpe doldurulduğunda içeride dolaşan bu iki gaz kendi rengini gösterme mücadelesi verir. Bazen havanın sıcak veya soğuk olması durumunda renklerden biri galip gelir (Hernandez, 2016) (Görsel 7).

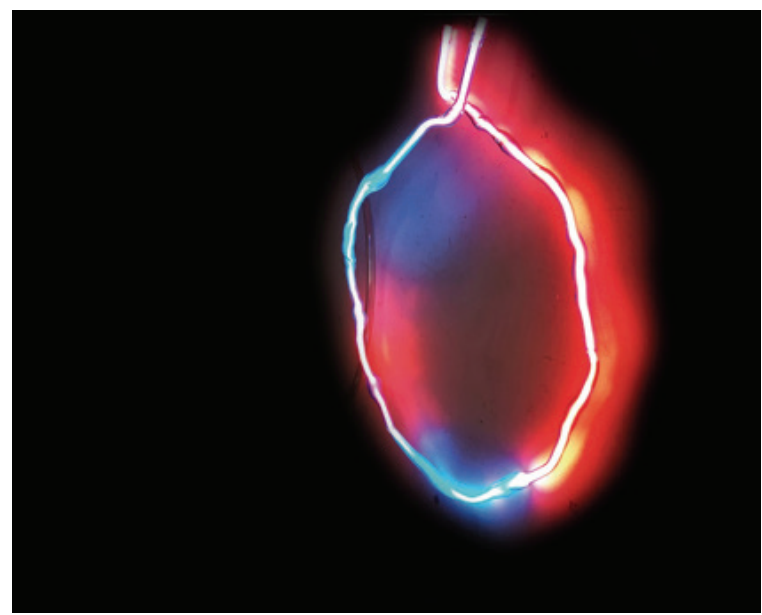

Görsel 7. Fatma Çiftçi (Yazar), "Mücadele”, $40 \times 30 \times 20 \mathrm{~cm}$, Cam, neon gazı, argon gazı, cıva buharı, 2016, Türkiye 
Gazın doldurulduğu tüplerin şeffaf olmaması durumunda, örneğin opal beyaz bir tüpe doldurulan argon-cıva gazı mavi yerine beyaz ışık gösterir. Bu amaçla yeşil, pembe, kahve renkli tüp camlar üretilmiştir, bazı tüplerin sürpriz renkler oluşturduğu kullanıcıları tarafından dillendirilmektedir (Hernandez, 2016). Tüp içerisine neon, argon, helyum, ksenon, kripton, radon gibi soygazların doldurulması, plazma ve neon üretimini mümkün kılar. Renklerin kuvveti 1şıkla birlikte doruğa ulaşırken bu teknikle metrelerce uzunlukta çizgisel görüntü yaratılabilir. Görsel 8'de gösterilen Michael Hernandez'in yerleştirmesindeki neon parçaların her biri 3,5 metre uzunluğundadır. Bu teknikle yapılan mekân yerleştirmeleri camı bükebilen sanatçılara olduğu kadar, karışık malzeme kullanan çağdaş sanatçılara da esin kaynağı olmuştur.

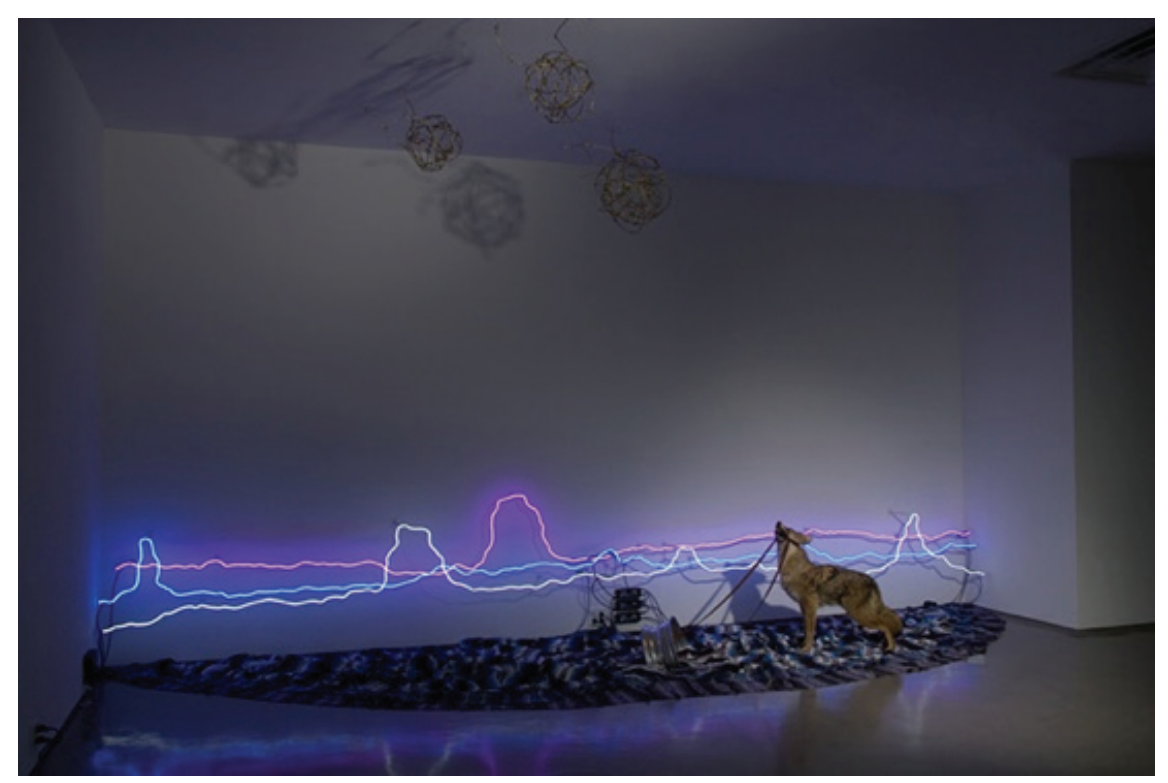

Görsel 8. Michael Hernandez, "The West is Tough, Amigo", 20x8x15" alan: 3,50 m., Neon, taksonomi çakal, falsa battaniyeleri, çelik tekerlek, dikenli tel, deri, boya, 2010, ABD

Renkle birlikte çizgisel ifadenin kullanımı İtalyan sanatçı Lino Tagliepietra’nın eserlerinde sıklıkla karşımıza çıkar (Görsel 6). Cam üfleme yöntemiyle oluşturduğu eserlerinde çizgileri renkli cam çubuklarla oluşturur, cam soğuduktan sonra soğuk şekillendirme aletleri yardımıyla cam üzerinde doku oluşturmaya başlar. Oluşturduğu dokuların da çizgisel olduklarını görürüz, böylece düz inen çizgileri farklı yönde taranmış yeni çizgilerle bölerek kırılma etkisi yaratır. 
Çizgisel ifadeye izin veren bir diğer olanak ise renkli üretilmiş plaka camların belirli incelikte kesilmesidir. Çizgi biçiminde kesilmiş camlar, füzyon tekniği ile birleştirilebilir, duvar heykelleri oluşturulabilir, roll-up tekniği ile üflenebilir. Üst üste füzyon tekniğiyle birleştirilen camlar soğuk cam işleme tekniğiyle kesilerek kesitlerindeki çizgisel değerler bir kompozisyon elemanı olarak kullanılabilir. Klaus Moje’nin bu teknikle yarattığı eserler oldukça fazladır (Görsel 9 ve 10). Alevde cam şekillendirme tekniğinde kullanılan cam çubuklar kesilerek de benzer etkide çizgisel değerler yaratılabilir.

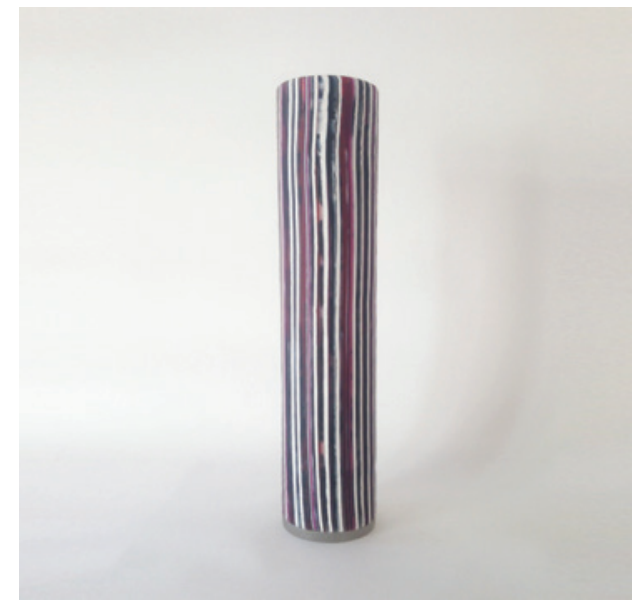

Görsel 9. Klaus Moje "Roll-Up”, Y: 61 G:13,5 cm, cam, 2010, Avustralya

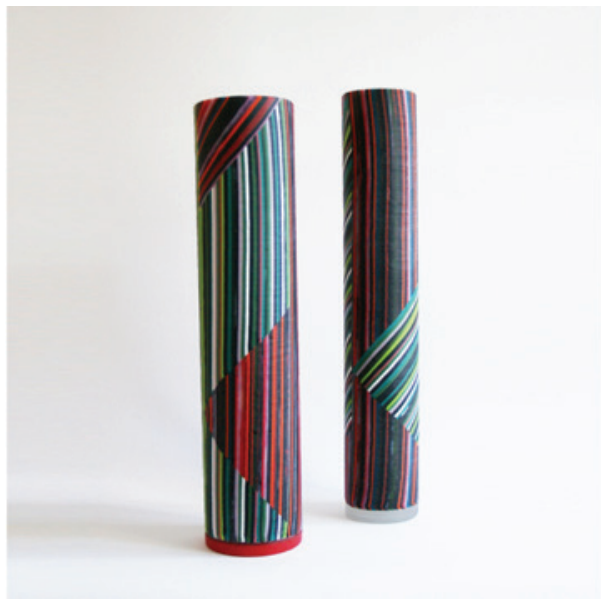

Görsel 10. Klaus Moje "Roll-Up 2", Y: 45 G:10 cm cam, 2012, Avustralya

Camda ışığın etkisiyle rengin ton değerlerinin arttığı da bilinmektedir. Bunun yanı sıra Görsel 11'de gösterildiği gibi bazı camlar gün ışı̆̆ında farklı renk, floresan ışıkta farklı renkte görünmektedir. Kullanılan camın yapısal özelliklerinden yararlanılarak elde edilen bu tür camlar, aynı form üzerinde farklı ışı kaynakları altında farklı renk seçenekleri sunulmasına olanak verir.

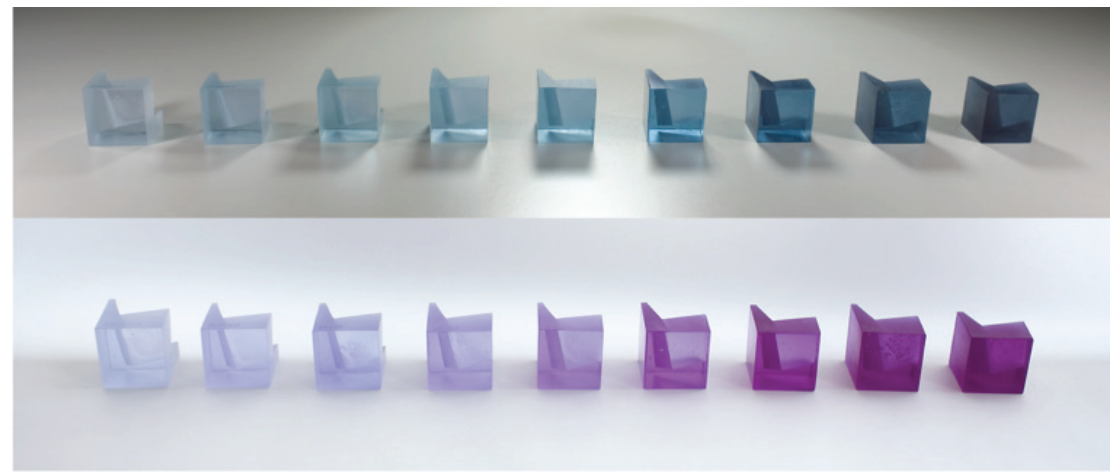

Görsel 11. Heike Brachlow, $3 \times 3 \times 6 \mathrm{~cm}$, Cam, 2012, Birleşik Krallik Neodimium doğrusal harman, gün ıșığında mavi ve floresan ıșığında mor (3 cm kalınlık) 


\section{CAMDA RENK VE ANLATIM İLIŞKİsi}

Cam kullanılarak oluşturulan bir eser, kavrama yaslandığında dahi göze yönelik baskın dekoratif özelliğiyle her iki niteliği de aynı bünyede barındırabilir. Sanat yapıtının değerlendirilmesinde göze yönelik sanat algısaldır, izleyicinin zihinsel anlamda ilginç bulmasını arzulayan, kavramanın işlevlerine hitap eden eserler ise kavramsal eserler olarak nitelendirilir (LeWitt, 1967: 197).

Rengin ışıkla birlikte ele alındığı tekniklerden plazma ve neon uygulamalarında, cam tüpler biçimlendirildikten sonra içleri gazla doldurulur. Renk verici özellik camın kendisinde olabildiği gibi, gazın kendisi de renk verme özelliğine sahip olabilmektedir. Bu malzeme bağlamında ışıkla birlikte renk konusu ele alındığında, çizgisel biçimlerle çok kuvvetli renklerin taşıyıcısı olan eserler ortaya çıktığı gözlenir. Plazma doldurulan camların ise biçimsel olarak, bilimsel deney veya bilim kurgunun fantastik niteliklerini taşıdığı görülür. Işık yüklü rengin içeride serbest şekilde dolaşması, parmağınızı değdirdiğinizde tüm plazmanın parmağınıza doğru toplanması onu büyülü bir interaktif deneyim haline getirir. Bu tekniği yıllardır kullanan sanatçılardan Ed Kirshner, heykellerine 'Aurora Sculptures' adını verir; gerçekten de teknik olarak Aurora, doğal plazmadır (Görsel 12). Camın belli belirsiz şeffaf sınırları nedeniyle plazma kendi başına biçim, ışık ve rengin aynı anda hareket ettiği dinamik bir alan ortaya çıarır. Bu haliyle plazma, camdan bağımsız, kendi halinde serbestçe dolaşan ışığın ta kendisi olarak anlatımda camın önüne geçer. Cam yalnızca onun içerisinde dolaştığı bir beden, kılıf veya kabuk görevi görür.

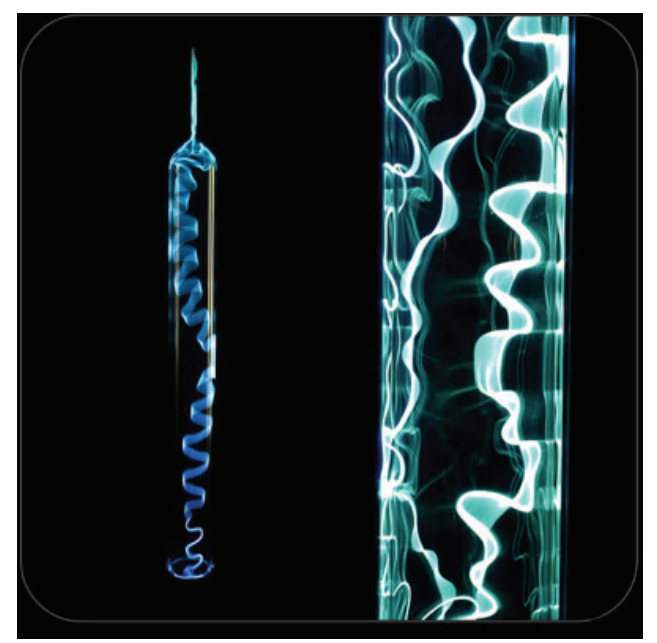

Görsel 12. Ed Kirshner, "Dewar Grande" 60x8x8, Pireks boru ve Ksenon gazı, Tarih bilinmiyor, ABD. 


\section{4.ÇALIŞMALARINDA RENGİ ESTETİK BİR SORUNSAL OLARAK KULLANAN SANATÇILARDAN ÖRNEKLER}

Renk unsurunu eserlerinde en çok kullanan sanatçılar aborjin kültürünün taşıyıcısı olan Avustralyalılardır. Genel olarak Avustralyalı sanatçıların camı çok renkli kullandıkları görülmektedir. Çok renkli çalışan Avustralyalı sanatç̧ları 1997 yılında Bullseye Cam Fabrikası tarafından desteklenmiş, kurumun ürettiği çok renkli camlar birer ticari ürün olmaktan çıkarak, sanatçıların ellerinde sanat eserlerine dönüşüp galeri ve müze mekânlarında statü kazanmıştır. Dönemin Bullseye Glass direktörü Lani McGregor, 1997 yılında Latitude çalıştayını takip etmek amacıyla Avustralyảnın Canberra kentini ziyaret eder; Avustralyảnın gelecek vaat eden dört genç sanatçısını seçerek onları Portland'daki Bullseye Cam Fabrikası'na davetli sanatçı olarak götürür (Osborne, 2013: 77). Bu sanatçılar; Canberra Cam Okulu’nun öğrencilerinden Giles Bettison (Görsel 13.), Claudia Borella, Mel George ve Jessica Loughlin'dir. Bir yılın sonunda 'International Young Artists in Glass: Australia' isimli bir sergi açlır ve sonraları bu sanatçılar, Bullseye Galeri tarafından temsil edilirler.

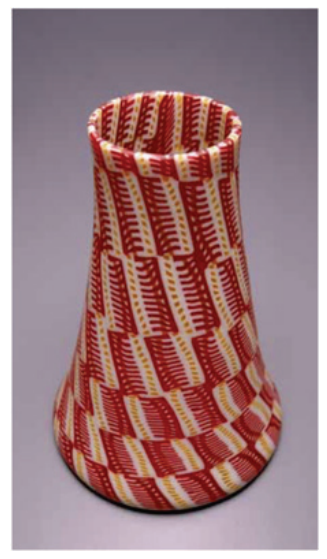

Görsel 13. Giles Bettison, "Magenta Vessel”, Boyut bilinmiyor, Cam, 1995, Avustralya

Avustralya’nın yılda bir kez düzenlediği prestijli yarışma olan Ranamok Glass Prize ödülünü (2004) kazanan Scott Chaseling’in eseri (Görsel 14.) Avustralya camcılı̆̆ının tüm karakteristik özelliklerini taşır; çok renklilik, karmaşı örüntülerin ustaca birleştirilmesi, roll-up tekniği ve birden fazla cam biçimlendirme tekniğinin kullanılmasıyla çarpıcı bir örnektir.

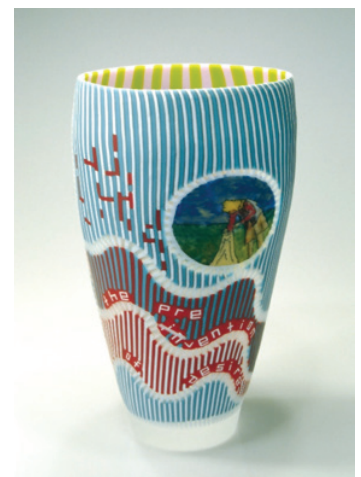

Görsel 14. Scott Chaseling, “Censor”, Y 47 x G 24 x D 24 cm., Cam: Füzyon, boyama, üfleme. 2004, Avustralya 
Avusrtalya’nın öncü cam sanatçlarından Klaus Moje’nin çağcılları olan Richard Marquis (Görsel 15) ve Nick Mount gibi üfleme tekniğini çalışan sanatçlların da çok renkli eserler ürettikleri görülmektedir.

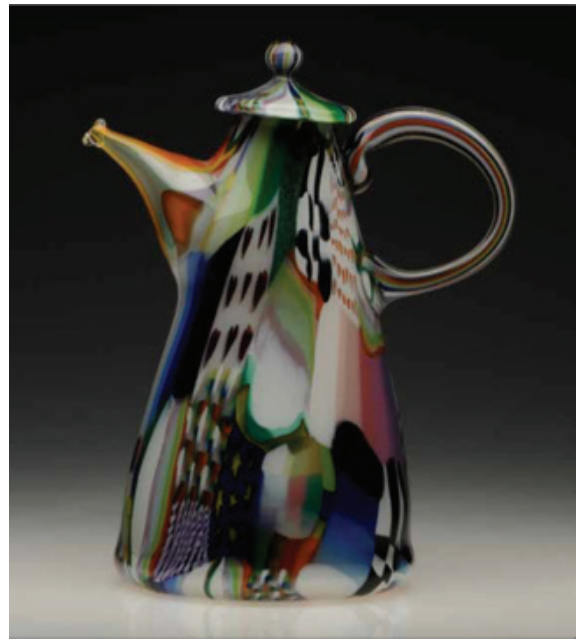

Görsel 15. Richard Marquis, “Crazy Quilt Coffee Pot”, Boyut bilinmiyor, Cam, 1974, Almanya

Avustralyảnın birinci kuşak çağdaş cam sanatçıları biçimsel olarak çizgisel değerlerle renk arayışında kompozisyonlar oluştururken ikinci kuşak daha çok kavrama yönelmiştir. Avustralya, 1970’lerden 1990'lara dek taşıdığı polikromik özellikleri bugün geride bırakmışsa da sanatçıları eserlerinde yine renk ve ışığı aramaktadır. Çağcıllarına paralel monokrom ve minimal özellikler gösteren eserlerinde Clare Belfrage’nin renge yaklaşımı dikkati çekmektedir. Çok katmanlı renkler ile oluşturduğu kompozisyonlarda rengin bulunduğu derinliklerin ışığı alma oranı eserin biçimiyle ilişkidedir (Görsel 16 ve 17).

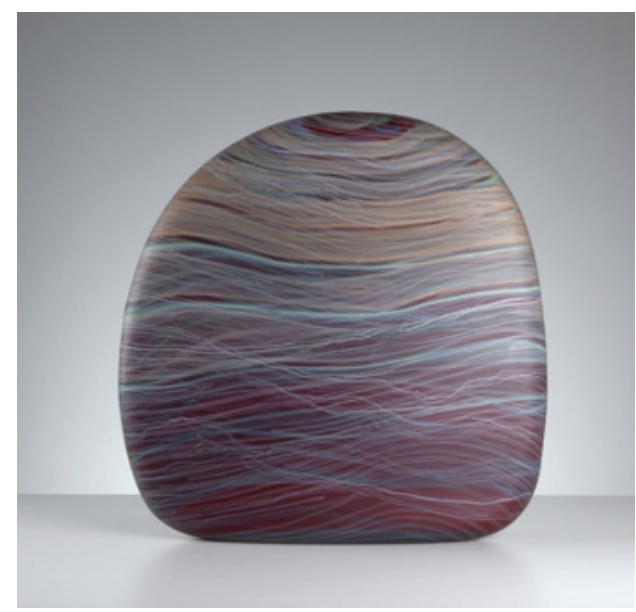

Görsel 16. Clare Belfrage "In Sight in Deep Red", Y: 44 G: 44 D: $9 \mathrm{~cm}$, Cam, 2015, Avustralya

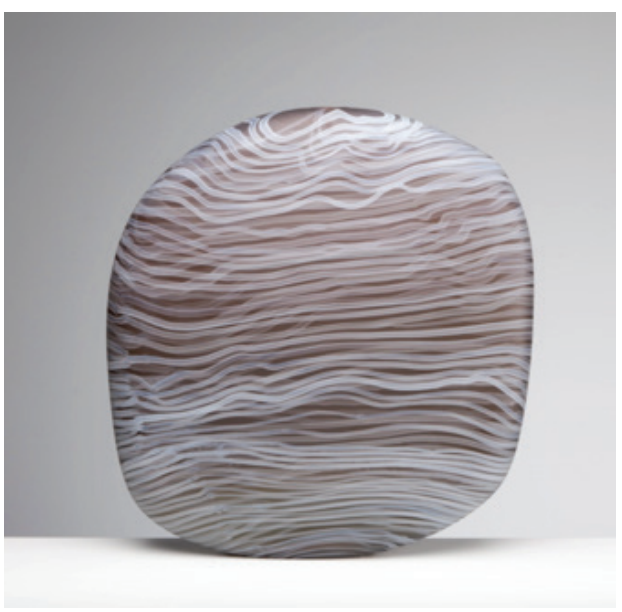

Görsel 17. Clare Belfrage "Awash in Brown", Y:35 G:33 D:6 cm, Cam, 2014, Avustralya 
Klaus Moje’nin renkle olan diyaloğu sürdüren biçimleri forma hareket kazandırarak izleyiciyi etrafında dolaşmaya davet eder. Rengin dinamiğini biçime ustaca aktaran sanatçı, izleyiciye hareket etmesi talimatını verir (Görsel 18). Kompozisyonlarının yapı taşları olan form, biçim, geometrik-inorganik, renk ve hatta malzeme dahi inorganiktir. Buna rağmen eserlerinde oluşturduğu yüksek kontrast veren etki, esinlendiği Aborijin kültüründen kaynaklanmaktadır (Görsel 18).

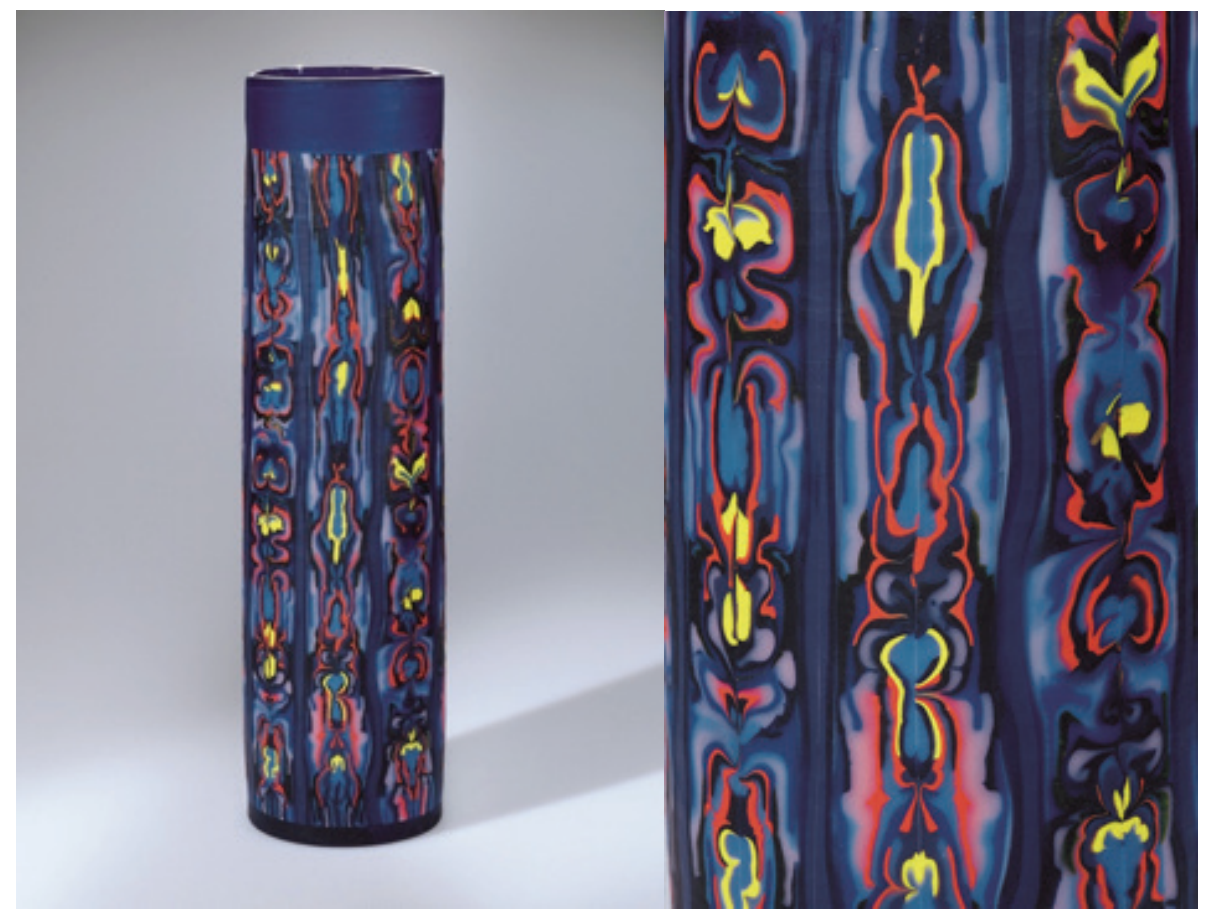

Görsel 18. Klaus Moje (Scott Chaseling ve Kirstie Rea asistanlığıla), "Niijima 10/99 B1", Y: 54 cm, G: 14.8 cm, Cam, 1999, ABD

Çok renkli cam çalışmalardan en bilineni İtalya'daki Venini Cam Fabrikası’ndan (1295) dünyaya yayılan murrina tekniğidir. Birinci Dünya Savaşı sonrası Venini Cam Fabrikası Vetreria Artistica Barovier adını alır ve Barovier ailesi tarafından yeniden yapılandırılır; Ercolo ve Nicolo Barovier kardeşler renkli karakteristik cam objelerin sınırlı üretimiyle piyasada fark yaratırlar (Sonego, 2004: 28). Aile mirası olan murrina tekniği ve mozaik camının stilize çiçekli süslemelerine ek olarak geometrik ve soyut motifler önermek suretiyle yeniden yorumlarlar ancak güncel ve çağdaş rakiplerinin gerisinde kalırlar (Sonego, 2004: 28). Bugün ise Barovier \& Toso ismiyle birleşirler ve ağırlıklı olarak geleneksel Venedik camcılığının postmodern yorumlarıyla işlevsel cam üretimine yoğunlaşmışlardır. Bugün rengi ustaca kullanan İtalyan cam ustası sanatçılarından Pietro ve Riccardo Ferro kardeşlerin, fonksiyonu dışlayan vazoları ve deniz yosunu biçimli heykelleri soyutlanmış murrina’ya referans verir (Görsel 19). 

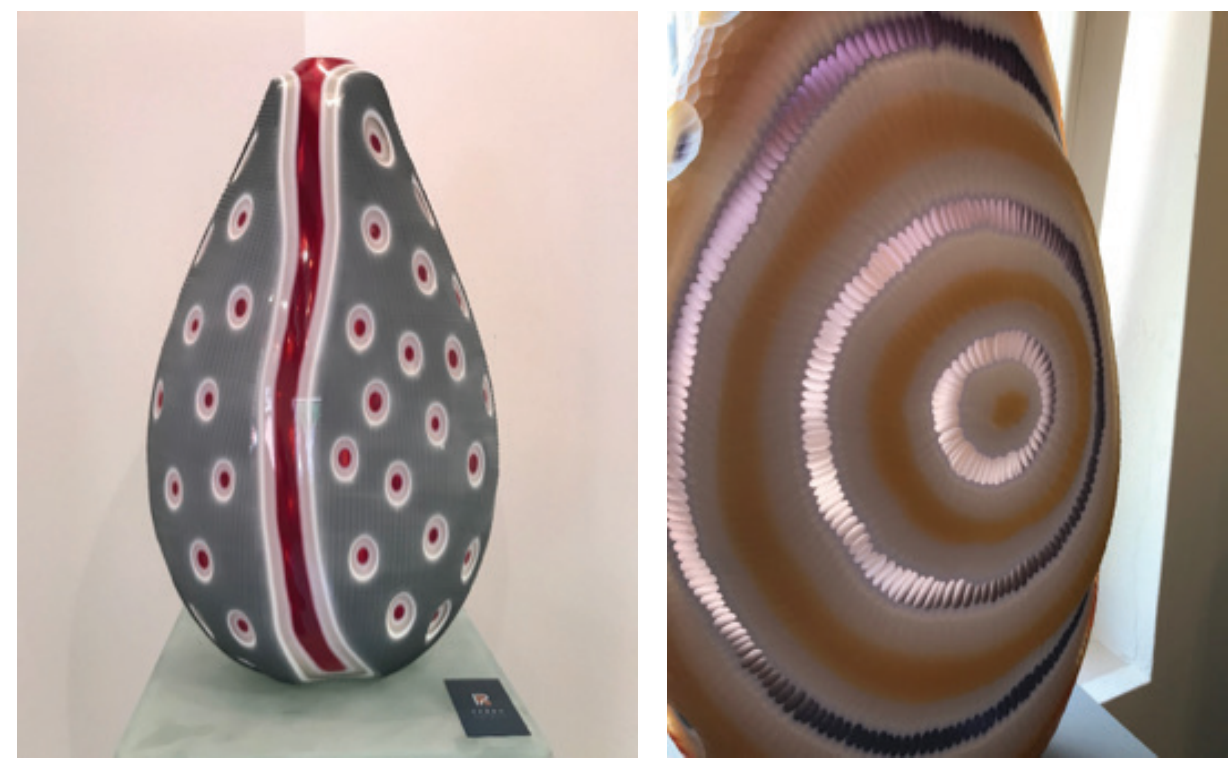

Görsel 19. The Ferro Brothers, "Red Line", $51 \times 30 \times 25 \mathrm{~cm}$, Cam, 2018, Ittalya

İskandinav camcılarının renge yaklaşımı ise oldukça farklıdır. Tasarımcılar oldukça sade ve şık koleksiyonlar ile dikkat çekerken, renkten ziyade forma yönelik önermelerde bulunurlar. Nordik ülkelerin belki doğmakta kararsız güneşi, bu toprakların tasarımcılarına renkleri monokrom algılatır. "Sevilen bir başka efsaneyse, İsveç’in yoksulluğu nedeniyle gösterişli ya da aşırı olmayan, olumlu yanından bakıldığında zarafet olarak nitelenebilecek bir tutumlulukla belirlenmiş bir form geleneği ortaya çıktığıdır.'(Jansson, 2014: 9).

Konu ve renk seçiminde karamsar davranmayan sanatçlar da mevcuttur. Yeni bir renk teorisi formüle etmeyi amaçladığını söylemekten sakınmayan günümüz sanatçlarından Olafur Eliasson (d.1967) renk üzerinde deneyler yapmayı sürdürür. Biçimsel olarak farklı bakış açılarından renklerin görüntüsüne müdahale eder ve ay tutulmasını andıran küre biçimleri oluşturur. Bazı açıdan karanlık, bazı açıdan renklerin izlenebildiği bu serileri sanatçı 'rengin ortaya çıkışı' olarak nitelendirir (Görsel 20).

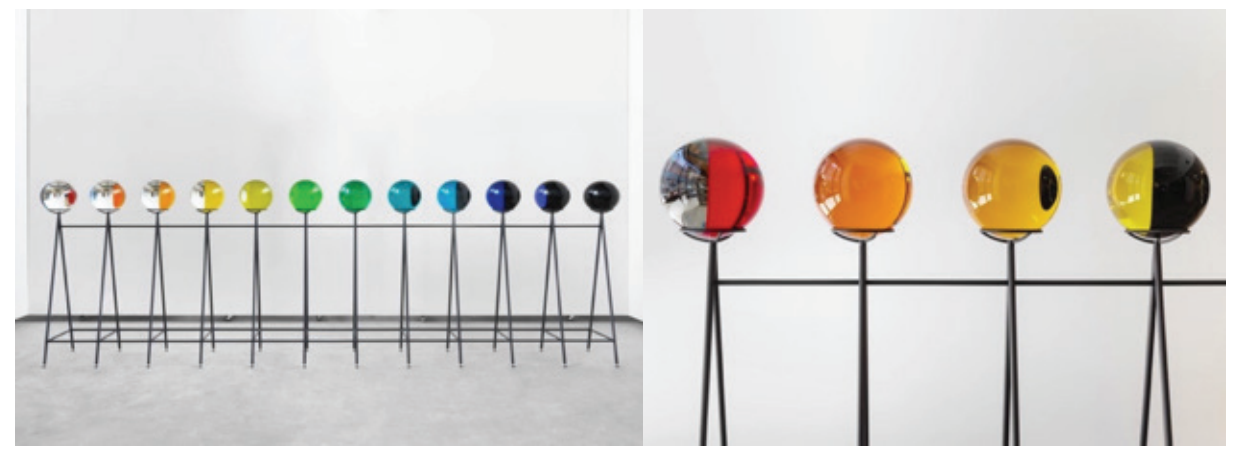

Görsel 20. Olafur Eliasson, "Rainbow Bridge", 12 parça cam küre ve metal konstrüksiyon, 2017, ABD 


\section{SONUÇ}

Birçok sanatçıya ilham kaynağı olmuş cam, bir malzeme olarak rengi bu denli farklı biçimlerde taşıyabilme özelliğiyle diğer malzemelerden kendini belirgin şekilde ayırır. Camla çalışan sanatçılar bir mimar gibi ışığı-dolayısıyla rengi- yönlendirmenin arayışındadırlar.

Sanatın diğer disiplinlerinde olduğu gibi cam kullanan sanatçılar için de renk; anlatımın taşıyıcısı olduğunda içerik, soyuta doğru bir ivme kazanır. Camın taşıdığı her renk, transparanlı̆̆ı ve ışı̆̆ı da içerir. Renkler koyulaştıkça içsel etkileri de derinleşir ve güçlenir. Cam malzemesinde aynı renkte tek bir kütlenin içerisindeki hacim farklllkkları renkte yoğunluğun azalmasına veya artmasına olanak săglar.

Malzemesi olan sanatçıların malzemeleriyle aralarında oluşan bağ, malzemenin fiziksel ve kimyasal özelliklerini içselleştirip onu doğasına uyumlu kullanmasında gözlenir. Cam kullanan sanatçılar biçimlerini oluştururken ışıktan ve renkten bağımsız düşünemezler. Örneğin açık renkli ve transparan özelliği yüksek bir cam kullanmanın biçime daha kırllgan bir anlam yükleyeceği içselleştirilmiştir.

Genel olarak Avustralyalı sanatçıların camı çok renkli kullandıkları görülür. Bugün rengi ustaca kullanan İtalyan cam ustası sanatçıları geleneksel murrina tekniğinin çok renkli ve karmaşık karakteristiğini yeniden yorumlarlar. İskandinav camcılarının renge yaklaşımı ise tam tersine monokromdur. Cam geleneğinden gelmeyen ancak camın fiziksel özelliklerini ustaca kullanan sanatçı Olafur Eliasson ise renk üzerinde yaptığı deneylerde yeni bir renk teorisi formüle etmeyi amaçladığını belirtir. 


\section{KAYNAKÇA}

Brachlow, H. (2012). Doktora Tezi. Shaping Color: Density Light and Form in Solid Glass Sculpture. s.127.

Cummings, K. (2011). Çağdaş Cam Sanatı. (Çev: M. Ağatekin), İstanbul: Karakalem Kitabevi Yayınları, s.21-49.

Jansson, M. (2014). Aurora Kuzey Ülkelerinden Çağdaş Cam Sanatı Sergi Kataloğu. İstanbul: Pera Müzesi Yayını. s.9.

LeWitt, S. (1967) Kavramsal Sanat Üzerine Paragraflar, (Çev: A. Antmen), (2008), 20. yüzyıl Batı Sanatında Akımlar içinde (s. 197), İstanbul: Sel Yayincılik.

Michael Hernandez ile 'Path of The Illuminati' eğitimi. 10.07.2016

M.Hernandez ile 13.07.2016 tarihinde yapılan yüzyüze görüşme.

Ocvirk, O.G., Stinson, R. E., Wigg, P.R, Bone, R. O., Cayton, D. L. (2015) Sanatın Temelleri. (Çev: Balkır Kuru, N., Kuru A.), Izmir: Karakalem Kitabevi Yayınları, s.184.

Osborne, M. (2013). Links Australian Glass and The Pacific Northwest. Seattle: University of Washington Press, s.77

Sonego, C. (2004). Ercole Barovier: A Protagonist of 20th Century Murano Glass. N. Bertoldini (Ed.), Venetian Art Glass: An American Collection, 1840-1970 içinde (28) Stuttgart: Arnoldsche Art Publishers.

Wittgenstein, L. (2007). Bemerkungen Über Die Farben, (2). (Çev: Linda L. McAlister Margarete Schaettle) U.S: University of California Press, s.7e, 8 e.

\section{GÖRSEL KAYNAKÇASI}

Görsel 1. http://www.ravenskyriver.com/home-1 (Erişim Tarihi: 22.06.2018)

Görsel 2. Shaping Color: Density Light and Form in Solid Glass Sculpture, Doktora Tezi, Yazar: Heike Brachlow, Royal College of Art, s.130.

Görsel 3. Shaping Color: Density Light and Form in Solid Glass Sculpture, Doktora Tezi, Yazar: Heike Brachlow, Royal College of Art, s. 124 .

Görsel 4. http://www.frantisekvizner.com/cut-glass/ (Erişim Tarihi:16.03.2017)

Görsel 5. Fatma Çiftçi Kişisel Fotoğraf Arşivi

Görsel 6. Fatma Çiftçi Kişisel Fotoğraf Arşivi

Görsel 7. Fatma Çiftçi Kişisel Fotoğraf Arşivi

Görsel 8. http://s3.otherpeoplespixels.com/sites/42003/assets/AnsVoif7jTiHLEhk.jpg (Erişim Tarihi: 24.04.2017)

Görsel 9. http://sabbiagallery.com/artists/klaus-moje/ (Erişim Tarihi: 09.02.2017)

Görsel 10. http://sabbiagallery.com/artists/klaus-moje/ (Erişim Tarihi: 09.02.2017)

Görsel 11. Shaping Color: Density Light and Form in Solid Glass Sculpture, Doktora Tezi, Yazar: Heike Brachlow, Royal College of Art, s.133.

Görsel 12. http://www.aurorasculpture.com/plasma/image13.htm (Erişim Tarihi: 16.04.2017)

Görsel 13. https://collection.maas.museum/object/161263 (Erişim tarihi: 30.06.2018)

Görsel 14. http://svc035.wic052p.server-web.com/finalists/finalist.cfm?eid=732 (Erişim Tarihi: 09.02.2017)

Görsel 15. Museum of Modern Glass (Kat. No:53) s. 12

Görsel 16. http://www.clarebelfrage.com/recent-work/ (Erişim Tarihi: 09.02.2017)

Görsel 17. http://www.clarebelfrage.com/recent-work/ (Erişim Tarihi: 09.02.2017)

Görsel 18.http://d3seu6qyu1a8jw.cloudfront.net/sites/default/files/images/99.6.8.jpg?itok=OU79TXfs) CMOG Koleksiyonu (Erişim Tarihi: 09.02.2017)

Görsel 19. Fatma Çiftçi Kişisel Fotoğraf Arşivi

Görsel20.http://olafureliasson.net/archive/artwork/WEK108815/your-museum-primer\#slideshow (ErişimTarihi: 16.04.2017) 